\title{
ANTHONY D. SMITH (1939-2016) JAKO SOCJOLOG NARODU. SZKIC DO PORTRETU INTELEKTUALNEGO
}

\author{
ANTHONY D. SMITH (1939-2016) \\ AS A SOCIOLOGIST OF NATION: \\ A SKETCH TO AN INTELLECTUAL PORTRAIT
}

\begin{abstract}
The aim of this article is to present a sketch of the intellectual biography of Anthony D. Smith who is the creator of the theoretical perspective in sociology of nation, called ethnosymbolism. The text analyzes the impact of his childhood and early school education in a later life as a scholar and his future research of nations. It also presents the stages of his education and the interest in national issues shaped at that time, in particular studies on ancient history, general historiography or classic sociological theories. The article shows three stages of the formation of Smith's scientific views, from consistent modernism, to its correction, to radical ethnosymbolism. The text is a sketch of an intellectual biography, not a detailed analysis of the ethnosymbolic approach itself.
\end{abstract}

Key words: Anthony D. Smith; history of sociological thought; sociology of nation; ethnosymbolism

\section{Streszczenie}

Celem artykułu jest zaprezentowanie szkicu biografii intelektualnej Anthony'ego D. Smitha, twórcy perspektywy teoretycznej w socjologii narodu nazywanej etnosymbolizmem. W tekście dokonana zostanie analiza wpływu dzieciństwa i wczesnej edukacji szkolnej uczonego na podejmowane przez
JACEK PONIEDZIAŁEK Uniwersytet Warmińsko-Mazurski w Olsztynie E-mail: jacek.poniedzialek@wp.pl https://orcid.org/0000-0003-3757-2750

CITATION: Poniedziałek, J. (2019). Anthony D. Smith (1939-2016) - jako socjolog narodu. Szkic do portretu intelektualnego. Sprawy Narodowościowe. Seria nowa, 2019(51). https://doi.org/10.11649/sn.1956

This work was supported by the author's own resources. No competing interests have been declared.

This is an Open Access article distributed under the terms of the Creative Commons Attribution 3.0 PL License (creativecommons.org/licenses/by/3.0/pl/), which permits redistribution, commercial and non-commercial, provided that the article is properly cited. (C) The Author(s) 2019

Publisher: Institute of Slavic Studies, Polish Academy of Sciences 
niego w przyszłości badania narodów. Ukazane zostaną etapy jego edukacji i ksztattujące się wówczas zainteresowania problematyką narodową, w szczególności studia nad historią starożytną, historiografią powszechną czy klasycznymi teoriami socjologicznymi. Wyodrębnione zostały trzy etapy formowania się poglądów naukowych Smitha, od konsekwentnego modernizmu, przez jego korektę, do radykalnego etnosymbolizmu. Tekst jest szkicem biografii intelektualnej, a nie szczegółową analizą samego podejścia etnosymbolicznego.

Słowa kluczowe: Anthony D. Smith; historia myśli socjologicznej; socjologia narodu; etnosymbolizm

W dniu 19 lutego 2016 roku zmarł Anthony D. Smith, jeden z najwybitniejszych wspołczesnych uczonych zajmujących się w socjologii problematyką narodu i nacjonalizmu. Brytyjski uczony opracował i rozpropagował własną koncepcję teoretyczną, która do historii nauk społecznych weszła pod nazwą etnosymbolizmu. Jego pozycja naukowa, waga dokonań intelektualnych i dyskusje, które wzbudzały jego pomysły, odcisnęły niezatarte piętno na socjologicznym, choć nie tylko, narodoznawstwie. Z tego chociażby względu warto postać wzmiankowanego uczonego przybliżyć. Niemniej, można odnieść wrażenie, że odejście tego wybitnego badacza przeszło w Polsce bez echa. Nie będę tu charakteryzował samej teorii autorstwa Smitha, celem tego artykułu jest prześledzenie biografii uczonego ze wskazaniem tych w niej momentów, które wydają się najbardziej istotne z punktu widzenia jego etnosymbolicznej teorii narodów Chcę naszkicować przyczynek do portretu intelektualnego brytyjskiego uczonego. Dokonania i przemyślenia wyrażane w publikacjach, teoriach i naukowych koncepcjach będą zrozumiałe, gdy umieścimy je w szerszym kontekście rodzinnym, społeczno-politycznym, kulturowym czy też naukowym i instytucjonalnym. Znaczy to tyle, iż aby zrozumieć twórczość naukową człowieka, trzeba poznać jego doświadczenia z dzieciństwa, formację edukacyjną i wychowawczą. Zarysować też trzeba trajektorię losów zawodowej kariery uczonego. Analiza rodzinnego, społecznego i intelektualnego uwikłania ludzi nauki w procesie wyjaśniania i krytycznego odtwarzania kategorii myślenia, stosowanych definicji i koncepcji stanowi niezbędny warunek wstępny ich analizy.

W pierwszej części postaram się ukazać dzieciństwo i edukację we wczesnych i nastoletnich latach badacza narodów. Chce pokazać wychowanie w rodzinie żydowskich emigrantów w Anglii oraz wpływ na świadomość uczonego i podejmowaną w przyszłości problematykę historii rodziny, w której tak ważną rolę odegrały Holokaust i doświadczany w szkołach podstawowej i średniej przez młodego Smitha antysemityzm, tak powszechny w Anglii późnych lat czterdziestych i pięćdziesiątych ubiegłego wieku. W dalszej kolejności opisze studia z filologii, filozofii i historii starożytnej i powszechnej w Oksfordzie i Brugii oraz studia z socjologii zakończone doktoratem na London School of Economics (LSE) w Londynie. Ostatni fragment poświęcam na szkic ścieżki kariery naukowej przynoszącej liczne publikacje i wypracowanie własnego etnosymbolicznego podejścia w studiach nad narodem i nacjonalizmem. Opiszę też skrótowo karierę akademicką brytyjskiego badacza, od początków na stanowisku wykładowcy socjologii na uniwersytetach York i Reading, aż po profesure na London School of Economics. 
Przyszły badacz problematyki narodowej przyszedł na świat w Londynie 23 września 1939 roku w rodzinie żydowskich emigrantów. Nadano mu imiona Anthony David Stephen. Wspominając dzieciństwo, Smith stwierdzit: „Mój ojciec był drobnym, pochodzącym z klasy pracującej, żydowskim przedsiębiorcą, był bardzo aktywny i sumienny, bardzo mądry, choć nie miał formalnego wykształcenia. W wieku lat czternastu zmuszony był porzucić szkołę" (Hall, 2016, s. 6). Rodzina ze strony ojca, nosząca nazwisko Rosenstrauch, od wieków zamieszkiwała w Polsce, jednak część tej rodziny opuściła kraj swego pochodzenia i osiedlila się w Niemczech. Z tego niemieckiego odgałęzienia rodziny wywodził się ojciec przyszłego znawcy prolematyki narodów i nacjonalizmu. Większość pozostalych w Polsce Rosenstrauchów oraz spokrewnionych z nimi 80 osób wymordowali naziści w komorach gazowych niemieckiego obozu zagłady w Treblince. Przodkowie ze strony matki także wywodzili się od aszkenazyjskich Żydów mieszkających w Polsce. Rodzina matki, nosząca nazwisko Gostyńscy, pochodziła ze wsi Tum nieopodal Łęczycy w dzisiejszym województwie łódzkim, miejscowości, w której rodziny żydowskie zamieszkiwały od XV wieku. Prowadzili tam gospodarstwo rolne. Babka przyszłego uczonego urodziła się w Łęczycy. Rodzina babki Smitha przeniosła się do Wiesbaden w Niemczech. Pozostali w Polsce członkowie rodziny zostali wymordowani, ich liczbę oszacowano na 40 osób (Hutchinson, 2016, s. 621). Rodzina matki różniła się od rodziny ojca swoim usytuowaniem klasowym, jak podkreśla sam uczony, byli to przedstawiciele solidnej klasy średniej (Hall, 2016, s. 6).

Matka badacza narodów, Harriet Gostyńska, odwiedziła Anglię w 1930 roku. Postanowiła pozostać tam dłużej, albowiem poznała ojca uczonego, który wemigrował na Wyspy Brytyjskie nieco wcześniej. Spotkanie i późniejsza znajomość zaowocowały ślubem w następnym roku. Młode małżeństwo zamieszkało w Londynie w dzielnicy Belsize Park. Ojciec opuścił rodzinę, kiedy Anthony miał dwa i pół roku, przez lata nie utrzymywali ze sobą kontaktu. W kwietniu 1933 roku niemieccy naziści zamordowali w Wiesbaden dziadka Smitha. Aresztowanej babce udało się uciec z domu tylnymi drzwiami. Wraz z piątką swych dzieci dostała się do bezpiecznej Anglii. Reszta rodziny po wydarzeniach Nocy Kryształowej 9 na 10 listopada 1938 roku uciekła do Stanów Zjednoczonych, niektórzy zaś dołączyli do krewnych osiadłych na Wyspach Brytyjskich. Babka uczonego zamieszkała w Londynie, pomagając córce wychować Anthony`ego, zapewniając mu w pierwszych latach życia „...bardzo konwencjonalne wychowanie, jakie zapewnia klasa średnia" (Hall, 2016, s. 7).

Anthony wychowywany był zgodnie z wartościami i normami społecznymi obowiązującymi w angielskiej klasie średniej. Językiem domowym rodziny Smitha był angielski, choć matka i babka używały niekiedy niemieckiego. W dzieciństwie uczył się „..W kilku szkołach z internatem, gdzie nie tylko nasiąkł miłością do świata klasycznego, ale spotkał się też z antysemityzmem" (Hutchinson, 2016, s. 621). Uczęszczając do szkoły św. Krzysztofa, poddany został intensywnej edukacji w duchu ortodoksyjnego protestanckiego chrześcijaństwa, co skłoniło jego matkę do rozpoczęcia edukacji religijnej i kulturowej syna. Kilkutetni Anthony zaczął pobierać naukę hebrajskiego, w rodzinie zaczęto też obchodzić żydowskie święta: żydowski Nowy Rok, święto Sedar rozpoczynające Paschę, obchodzono także szabas. Smith stał się dzieki temu świadomy swojej żydowskości, która na resztę życia stawowić będzie integralną część jego osobowości.

W wieku ośmiu lat wysłany został do szkoły Dane Court, Whatcombe nieopodal Blandford w hrabstwie Dorset. W tej szkole z internatem uczył się w latach 1948-1951, 
w szczególności przedmiotów klasycznych, z naciskiem na sztukę i historię. Intensywnie uczył się łaciny i francuskiego. Zetknął się tu z przejawami antysemityzmu zarówno ze strony kolegów, jak i części nauczycieli. Nacjonalistyczne postawy powojennego społeczeństwa brytyjskiego były reakcją na II wojnę światową, a także na wywołaną przez nią falę migracji, w szczegolności z krajów Europy Środkowo-Wschodniej zajętych przez Związek Radziecki. Wśród tych migrantów znajdowali się również Żydzi z tamtej części świata. Część brytyjskiego społeczeństwa obwiniała Żydów za spowodowanie wojny, a także obarczała ich winą za powojenny kryzys, który dotknął Wielką Brytanię. Wskazane zjawiska wpływały na rosnący w tym kraju antysemityzm, na którego popularność dodatkowo wpływała kwestia wybijającego się na niepodległość Izraela w tamtych latach, co wiązało się z podjęciem przez syjonistów walki zbrojnej z Brytyjczykami sprawującymi kontrolę nad ówczesną Palestyną (Zins, 2001, s. 396).

Kilkuletni Anthony i jego rodzina doświadczyli antysemityzmu, i to doświadczenie nigdy się w pamięci uczonego nie zatrze, dając asumpt do poźniejszych przemyśleń nad nacjonalizmem i etnicznymi wizjami narodu. Drogą do pełnego wejścia w naród brytyjski była asymilacja, wymogi tego procesu „...zmusiły wielu Żydów do wyjścia ze wspólnoty, do przyjęcia radykalnej filozofii społecznej i politycznej, a nierzadko także do zmiany brzmienia nazwisk na angielskie. Ambitni młodzi ludzie mogli szukać wyjścia, ukrywając swoje żydowskie pochodzenie" (Davies, 2007, s. 855). Rodzina przyszłego uczonego początkowo wybiera taką właśnie strategię mimikry, zmieniono nazwisko na Smith brzmiące z brytyjska, używano języka angielskiego. Żydowskość objawiająca się kultywowaniem żydowskich świąt, rytuałów i symboliki, wspominaniem żydowskiej historii stała się sprawą ściśle prywatną.

Przez dwa lata Anthony uczył się w szkole w Woking, w Surrey w południowej Anglii. W wieku 13 lat przeniósł się do kolejnej szkoły z internatem, Bryanston School, niepodal Blandford w hrabstwie Dorset. Tam kontynuował naukę zgodnie z klasycznym kanonem przedmiotów wykładanych w tamtym czasie w brytyjskich szkołach. Przyswajał wiedze dotyczącą świata starożytnego, greckiej historii i greckich mitów, Rzymu czy starożytnego Egiptu, uczył się języków. Formowany jak przedstawiciel angielskiej wartstwy inteligenckiej, miał w przyszłości solidną baze do rozwijania historycznej socjologii narodów i nacjonalizmu. Jak będzie to widać w opublikowanych w dorosłym życiu książkach, jego erudycyjna wiedza z historii, literatury i sztuki będzie wyróżniać go spośród wielu innych uczonych zainteresowanych problamatyką narodów. W tej szkole porzucił strategię mimikry, odkrywając na nowo swoje żydostwo. Wraz z kilkoma innymi żydowskimi uczniami uczestniczyl w zajęciach z judaizmu przowadzonych przez reformowanego rabina. Nie bez wpływu na późniejsze poglądy naukowe pozostanie jego gruntowne wykształcenie, a także antysemityzm, którego doświadczał, oraz będący w pewnym sensie tego konsekwencją zwrot ku własnej żydowskości.

Początkowo wszystko zapowiadało, że młody Anthony Smith zostanie akademikiem zajmującym się epoką klasyczną, intensywnie bowiem uczył się łaciny, greki i historii starożytnej. Jak sam wspominał pewnego sierpniowego popołudnia w 1954 roku, jako piętnastolatek przechadzając się po korytarzach biblioteki w szkoły w Bryanston natknął się na książkę opisującą losy ludności żydowskiej w Niemczech w latach 1933-1934. W tej książce, przez przypadek niemal wyjętej spośród setek innych zalegających półki publikacji, piętnastoletni Smith odnalazł reprint artykułu z "Frankfurter Zeitung", w którym w beznamiętny sposób reporter opisał rozstrzelanie w Wiesbaden kwadrans po godzinie 21 w sobotę 21 kwietnia 1933 roku dwóch osób. Jedną z tych osób był dziadek przyszłego 
badacza problematyki narodów i nacjonalizmu. Od tego momentu zaczął on intensywnie studiować dzieje rodziny, o której historii niewiele wcześniej wiedział. Pogłębiał wiedzę na temat losów rodziny unikającej pogromów w carskiej Rosji, czy historię ucieczki jej członków z nazistowskich Niemiec.

Poznat traumatyczną opowieść o Holokauście, w którym śmierć poniosło tak wielu jego krewnych. Ten moment w życiu określit jako najważniejszy dla swoich przyszłych naukowych losów. Pod koniec życia stwierdzit, że „...to był z pewnością główny punkt zwrotny [w życiu - przyp. J.P.], choć w owym czasie nie było to oczywiste. To jedna z tych rzeczy, które wbijają się w duszę i stopniowo, stopniowo przynoszą swój skutek" (Hutchinson, 2016, s. 10). Osobiste doświadczenia związane z antysemityzmem oraz pamięć o żydowskiej rodzinie, a także historia Holokaustu wpłynęły na jego zainteresowania badawcze skupiające się wokół problematyki narodu i nacjonalizmu. Co jednak równie istotne, uformowały jego liberalne i demokratyczne poglądy polityczne w odniesieniu do jego brytyjskości, a także ukształtowały jego umiarkowanie syjonistyczny światopogląd w odniesieniu do kwestii żydowskiej, której w jego mniemaniu najlepszym rozwiązaniem było powstałe po II wojnie światowej państwo Izrael (Conversi, 2004, s. 283).

John Hutchinson, podkreślając wagę tych doświadczeń w życiu uczonego, stwierdzit, iż ich rezultatem była „....intensyfikacja przejawiającego się w całym późniejszym życiu zainteresowania historią i kolejami losów Żydów, na podstawie znajomości których uświadomił sobie istnienie narodów w świecie starożytnym" (Hutchinson, 2016, s. 621). Smith przez całe późniejsze życie podkreślał będzie wage historii jego rodziny w decyzji odnośnie do swoich zainteresowań naukowych. Twierdzit, że przedmiotem swoich studiów, a następnie badań uczyni narody i nacjonalizmy. „Co więcej, osobiste doświadczenie antysemityzmu w szkołach podstawowej i średniej w Anglii tuż po zakończeniu II wojny światowej uwrażliwiło go na problematykę różnic religijnych i kulturowych" (Malešević, 2016, s. 154). Owe doświadczenia wpłynęły również na rozwinięcie zainteresowań problematyką, której badaczem i niewątpliwym znawcą Smith zostanie w przyszłości.

\section{EDUKACJA AKADEMICKA}

Jako bardzo pilny uczeń Smith dostał stypendium, które umożliwiło mu podjęcie studiów klasycznych na Uniwersytecie w Oksfordzie. Studia rozpoczęte w 1958 roku wyposażają go w niezwykle solidną wiedze w zakresie historii i filozofii, literatury i kultury starożytnej Grecji i Rzymu. Jak zaznacza Walker Connor, w późniejszym okresie jego aktywności naukowej stanie się niezbędna w konstruowanej etnosymbolicznej teorii nacjogenezy rozumianej jako proces longue durée (Connor, 2004, s. 35). Podczas studiów zainteresowała Smitha również problematyka powstawania narodów i państw narodowych w rozpadającym się Imperium Brytyjskim. Wówczas to pojemna kategoria brytyjskości zaczęła być konstruowana na nowo, ograniczając się w zasadzie do narodów i grup etnicznych zamieszkujących Wyspy Brytyjskie. Pobudziło to rozwój brytyjskiego, a nawet angielskiego nacjonalizmu jako swego rodzaju reakcji na te procesy. Wpłynęło również na swoiste przebudzenie etniczne i narodowe w Walii i Szkocji (Davies, 2007, ss. 857-859).

W czasie studiów w Oksfordzie zaangażował się w życie żydowskiej wspólnoty, która $w$ tym miejscu była relatywnie liczna i niezwykle aktywna. Utrzymywał silne relacje z żydowskimi studentami i emigrantami pochodzącymi z Polski. Nawiązał kontakt z ocala- 
łym z Holokaustu kuzynem Leo Gostyńskim. Po wielu staraniach odwiedził w 1961 roku mieszkającego w Warszawie krewnego. Ten oprowadził go po stolicy Polski, pokazując miejsce getta. Zabrał go do Tumu i Łęczycy, miejsc pochodzenia rodziny jego matki. W powojennej Polsce, będącej cmentarzyskiem narodu żydowskiego, na miejscu gdzie Niemcy wymordowali znaczną jego część, słuchał opowieści Leo Gostyńskiego o szerzącym się w komunistycznej Polsce antysemityzmie. Konfrontował te opowieści z własnymi doświadczeniami z dzieciństwa. Jak stwierdzał we wspomnieniowym wywiadzie, z antyżydowskim resentymentem przestał się spotykać dopiero w akademickim środowisku Oksfordu (Hall, 2016, s. 11). Poza swoistym szokiem, jaki wywołał w nim polski antysemityzm bujnie krzewiący się w kraju tak dotkniętym rasistowską polityką III Rzeszy, zainteresował się także historią Polski, w szczególności procesami powstawania i przekształcania się narodu polskiego. Co ważne, w rozwijanych w późniejszych latach etnosymbolicznych teoriach narodu i nacjonalizmu będzie formułowane tezy i twierdzenia wspierał niejednokrotnie egzemplifikacjami czerpanymi właśnie z historii Polski.

$\mathrm{Na}$ oksfordzkim uniwersytecie pogłębiał wiedzę w zakresie języków klasycznych oraz studiował historię i filozofię starożytną. W trakcie studiów poznał historyka Georga Forresta ${ }^{1}$, który zainteresował Smitha otwartym spojrzeniem na historiografię, ukazując mu konieczność widzenia dziejów jako procesów długiego trwania, które pomimo wykazywania wielu prawidłowości zależą od społecznych i kulturowych kontekstów, w jakich zachodzą. Ten sposób widzenia procesów historycznych znajdzie potem odbicie w jego naukowym pisarstwie. Nie udało się Smithowi uzyskać stypendium zapewniającego kontynuację studiów w Oksfordzie. Udaje mu się jednak uzyskać miejsce w belgijskim College d’Europe w Brugii. Tam zaczą interesować się socjologią. Profesor nauk politycznych, wywodzący się ze środowiska oksfordzkiego John Bowle ${ }^{2}$ na kanwie wydarzeń na Bliskim Wschodzie z początku lat sześćdziesiątych ubiegłego wieku (tj. zapoczątkowane w 1948 roku zbrojne konflikty izraelsko-arabskie), postanowił prowadzić seminarium poświęcone nacjonalizmowi. Student z Anglii zapisał się na owo seminarium, na nim napisał pierwszy esej poświęcony problematyce narodowej, była to praca o syjonizmie. Na jednym z zajęć profesor Bowle rozdawał tematy esejów, tak wspominał to sam brytyjski badacz narodów: „Pani po mojej prawej stronie powiedziała, że bierze temat arabskiego nacjonalizmu, ja powiedziałem, w porządku, ja mogę wziąć żydowski nacjonalizm, niewiele się nad tym wówczas zastanawiając. Studiowałem żydowski nacjonalizm końca XIX wieku. To po raz drugi otworzyło mi oczy na uwarunkowania problemów Żydów późnego XIX wieku w centralnej Europie, co było niezwykle ważne dla mojego rozumienia tego zjawiska, jak się później okaże" (Hall, 2016, s. 13)

Zainteresowanie socjologią wymusiło podjęcie studiów tej dyscypliny, zaś uczestniczenie w seminarium poświęconym nacjonalizmowi uczyniło koniecznym podjęcie pogłębionych studiów nie tylko z historii, ale i będących ówcześnie w obiegu naukowym

William George Grieve Forrest (1925-1997) - wybitny historyk, urodził się w Glasgow w Szkocji, wyksztatcit się na University College School, Hampstead. Wykładowca na uniwersytecie w Oksfordzie, od 1977 r. profesor historii starożytnej na tejże uczelni. Autor takich dziet jak: The Emergence of Greek Democracy, 800-400 B.C. (1966) i A History of Sparta, 950-192 B.C. (1968).

2 John Edward Bowle (1905-1988) - angielski historyk. Ukończył studia na uniwersytecie w Oksfordzie w 1927 r., po studiach pracowat jako nauczyciel w Westminster School i Eton College. W latach 1947-1949 wykładał na Wadham College w Oksfordzie. W latach 1950-1967 pracowat jako profesor nauk politycznych na College d’Europe w Brugii w Belgii. Wówczas na jego zajęcia z nacjonalizmu uczęszczał Anthony D. Smith. Pracowat również na Uniwersytecie Columbia czy Indiana i innych amerykańskich uczelniach. Autor wielu książek, m.in.: Politics and Opinion in the Nineteenth Century (1954), Man Through the Ages, from the Origins to the Eighteenth Century (1963), The English Experience: A Survey of English History from Early to Modern Times (1971). 
teorii narodu i nacjonalizmu. W trakcie rocznych studiów w kontynentalnej części Europy, rok akademicki 1962/63, Smith uczył się od swoich wykładowców, że nacjonalizm jest zjawiskiem martwym w jednoczącej się Europie. Kiedy jednak generał Charles de Gaulle rządzący ówcześnie Francją odrzucił prośbę Brytyjczyków o członkostwo we Wspólnotach Europejskich, obserwował erupcję postaw nacjonalistycznych, zarówno w Anglii, jak i w V Republice (Hutchinson, 2016, s. 662). W tym samym czasie w Belgii zaobserwował procesję Bożego Ciała, której uczestnicy odwoływali się do mitów Żydów bogobójców, którzy wiecznie będą potępieni, zaś narody chrześcijańskie jako wybrane i nieskalane mają misję, którą wypełniając będą zbawione. To uzmysłowiło mu siłę mitów i odwołań religijnych stale obecnych i silnie odziaływających na dwudziestowieczne narody Europy.

Obserwacja religijnego rytuału reprodukującego religijny mit narodowy nasunie mu myśl o tym, jaką wagę w procesach narodotwórczych mają rytuały religijne i quasi religijne. Pchnie go to w późniejszym czasie do intensywnego studiowania twórczości Emila Durkheima i pism jego uczniów. To z nich przejął Durkheimowskie w istocie rozumienie narodu jako wspólnoty moralnej traktowanej przez swoich członków jako święta zbiorowość, która aby istnieć, musi być regularnie i cyklicznie potwierdzana poprzez odtwarzanie symboli i rytuałów. Wspomnienia o wspólnych przodkach członków narodu, kult pamięci poległych w wojnie bohaterów w społeczeństwach nowoczesnych niewiele różnią się od żydowskich mitów i świąt, gdzie przykładowo celebruje się ucieczkę z Egiptu, czy chrześcijańskich ceremonii upamiętniających ukrzyżowanie Chrystusa. Grupowe rytuały odtwarzające moralność narodu muszą być odtwarzane relatywnie często po to, by nie dopuścić do poluzowania solidarności społecznej, co w efekcie przyniosłoby dezintegrację społeczną narodu (Durkheim, 2010, s. 427).

Podczas studiów zaczął samodzielnie zapoznawać się z pismami Durkheima, poszerzał również swoją wiedzę socjologiczną, czytając pisma Marcela Maussa. Jak zauważa Steven Grosby, relacjonując swoją znajomość z twórcą perspektywy etnosymbolicznej, potwierdził swoje wcześniejsze intuicje dotyczące symbiotycznego związku sacrum, jako jednego z podstawowych wymiarów życia z etnicznością i narodami (Grosby, 2018, s. 258). W tamtym czasie, jak sam niekiedy wspominat, uważnie studiował również pisma innych klasyków myśli socjologicznej, takich jak Max Weber czy Georg Simmel, czy nawet niezbyt ceniony Karol Marks (Kerr, 2019, s. 104). Nie tylko jednak pisma klasyków stały się dla niego źródłem socjologicznych inspiracji. Czytał teksty zdobywających popularność wówczas autorów piszących $w$ ramach paradygmatu strukturalno-funkcjonalnego i modernistycznego, a także niezwykle wówczas popularnego na zachodzie Europy paradygmatu marksistowskiego. Wskazane nurty teoretyczne staną się przedmiotem jego krytyki. Co również istotne, w tamtym właśnie czasie zainteresował się pracami historyków z durkheimowskiej szkoły Annales, gdzie tworzyli uczeni tej miary co Marc Bloch, Lucien Febvre czy później Ferdynand Braudel. Tego ostatniego koncepcja historycznych analiz w perspektywie longue durée stanowić będzie ważny element intelektualnej konstrukcji tworzonego autorskiego przedsięwzięcia noszącego nazwę etnosymbolizmu (Özkirimli, 2003, s. 340).

Po powrocie z College d'Europe Smith przez rok pracował dla lokalnego urzędu, aby zdobyć pieniądze na dalsze studia. Zamierzał bowiem w sposób regularny i zinstytucjonalizowany pogłębiać wiedzę z zakresu socjologii, której fundamenty zdobył podczas studiów w Belgii. Po powrocie do Wielkiej Brytanii zaczął odkrywać rodzącą się dopiero socjologię w jego kraju, intensywnie studiował lepiej rozwiniętą brytyjską antropologię społeczną. Zdecydował się na podjęcie studiów magisterskich z socjologii na London School of 
Economics. Zdał egzaminy u młodego wówczas wykładowcy, historyka i socjologa Keitha Hopkinsa ${ }^{3}$. To twórczość tego badacza, uprawiającego socjologię historyczną, w dużym stopniu wpłynęła na to, iż on sam w przyszłości tej właśnie perspektywie przyzna pierwszeństwo w studiach nad narodami i nacjonalizmem. W trakcie studiów na tej uczelni zapoznał się dogłębnie z pracami uznanych badaczy, historyków, socjologów czy antropologów zajmujących się narodami i nacjonalizmem (Jaskułowski, 2009, s. 280). Są to dzieła między innymi Edwarda Halletta Carra, Carltona Hayesa, Karla Deutscha czy Hansa Kohna oraz Hugh Seton-Watsona ${ }^{4}$.

Szczególne wrażenie wywarła na nim praca Ernesta Gellnera Thought and Change, opublikowana w 1964 roku, zwłaszcza poświęcony narodom i nacjonalizmom rozdział siódmy. W nim bowiem autor wyłożył fundament tego, co potem będzie nosić nazwę modernistycznej teorii narodów. Gellner, odwołując się między innymi do teorii Durkheima, opisuje przejście od zbiorowości chłopskich do masowych społeczeństw państw industrialnych, w których nacjonaliści tworzą naród, przystosowując zbiorowości do warunków funkcjonowania industrialnego kapitalizmu. Praca zachwyciła Smitha, utwierdzając go w przekonaniu o wadze problematyki narodów i nacjonalizmu w socjologii, oraz o heurystycznej doniosłości teorii Durkheima, którą w późniejszych latach wplatał będzie we własne rozważania. Wskazana praca na tyle mocno wpłynęła na jego naukowe podglądy, że na czas jakiś na margines zepchnął zainteresowania i inspiracje pracami, które studiował podczas pobytu w Belgii. Nie dotyczy to Durkheima, który na zawsze stanie się ważnym źródłem intelektualnych inspiracji Smitha. Pracę magisterską, której tematem był nacjonalizm, napisał pod kierunkiem socjologa Percy Cohena ${ }^{5}$. Jak sam powiadał, studia jakie przedsięwziął w celu napisania pracy magisterskiej, ukażą mu „...spektrum idei i podejść, jakie można wykorzystać w badaniu nacjonalizmu" (Hall, 2016, s. 14).

Po obronie pracy magisterskiej Smith postanowił poświęcić się badaniu narodów i nacjonalizmu, co wyraził zgłoszeniem woli napisania doktoratu z tej właśnie problematyki na LSE. Jako promotor dysertacji wyznaczony został Ernest Gellner. Poświęcona została ona analizie naukowych teorii opisujących nacjonalizm, po latach zostanie opublikowana pod

\section{$\cdots \cdot \cdots$}

3 Morris Keith Hopkins (1934-2004) - brytyjski historyk i socjolog. Ukończył studia klasyczne na Uniwersytecie w Cambridge, w latach 1961-1963 wykładał socjologię na Uniwersytecie Leicester. Następnie wykładał historię starożytną w King`s College, w tym samym czasie, w latach 1963-1967 pracowat na London School of Economics. Wówczas poznał go Smith, będąc pod wrażeniem uprawianej przez niego historycznej socjologii i socjologizującej historii. Dwa lata 1967-69 wykładał socjologię na Uniwersytecie w Hong Kongu, i na LSE w latach 1970-1972. Od roku 1972 uczył socjologii na Uniwersytecie Brunel, by w 1985 r. otrzymawszy profesurę w zakresie historii starożytnej wrócić na Cambridge, gdzie pracował do przejścia na emeryturę w 2000 r. Napisat m.in.: Conquerors and Slaves (1978) czy A World Full of Gods: The Strange Triumph of Christianity (1999).

4 George Hugh Nicholas Seton-Watson (1916-1984) - brytyjski historyk i politolog specjalizujący się w problematyce Europy Środkowej i Wschodniej. Ukończył w 1938 r. Uniwersytet w Oksfordzie, gdzie rozpoczął prace w charakterze wykładowcy w 1945 r. W latach 1951-1983 zajmował stanowisko profesora historii Rosji na Uniwersytecie Londyńskim. Znawca dziejów nowożytnych Rosji i Europy Środkowo-Wschodniej. Zajmowała go również problematyka narodów i nacjonalizmów, czemu dał wyraz w takich publikacjach jak: Nationalism and Communism: Essays, 1946-1963 (1964), Nationalism Old and New (1965). Do najważniejszych jednak jego publikacji należy Nations and States: an Enquiry into the Origins of Nations and the Politics of Nationalism (1977), w której wykłada perenialistyczną teorię narodu, zgodnie z którą narody są zjawiskami długiego trwania i ich stare i trwałe formy w Anglii czy Francji, istnieją już od wczesnego średniowiecza, zaś narody Europy Środkowej i Wschodniej to w znacznej mierze produkty nowoczesnej ideologii nacjonalistycznej. Warto wymienić w tym kontekście jeszcze Language and National Consciousness (1981).

5 Percy Saul Cohen (1928-1999) - południowoafrykański i brytyjski antropolog i socjolog. Urodził się w Durbanie w Afryce Południowej, gdzie studiował w Uniwersytecie Witwatersrand w Johanesburgu. Od 1948 r, w Wielkiej Brytanii, gdzie studiował antropologię społeczną w okresie 1952-1960 przygotowując pracę doktorską na temat migrantów kształtujących powstające państwo Izrael. Studiował również na Uniwersytecie Hebrajskim w Jerozolimie w okresie 1953-1958, łącząc to ze studiami w LSE. W okresie 1960-1965 wykładał socjologię na Uniwersytecie Leicester, następnie przeniósł się na LSE, gdzie w roku 1971 uzyskał profesurę. Zajmowała go problematyka żydowska, a także współczesna teoria socjologiczna. 
tytułem Theories of Nationalism. Była to pierwsza monografia naukowa autorstwa przyszłego twórcy perspektywy etnosymbolicznej (Hutchinson, 2016, s. 622). Praca doktorska zostaje obroniona w 1969 roku. Kontakty z promotorem, który w późniejszym okresie stanie się jednym z głównych naukowych adwersarzy, były bardzo formalne. Smith wspominat, że w wymiarze naukowym uzyskat wiele wsparcia od Gellnera, natomiast ich relacje osobiste były bardzo oficjalne. Promotor pracy udzielał wielu cennych wskazówek naukowych, był otwarty na pomysły i przemyślenia młodego adepta studiów nad narodem i nacjonalizmem. Natomiast nie wytworzyła się pomiędzy nimi bliższa wieź osobista. Smith wspominat, iż tylko raz został zaproszony na lunch przez swojego promotora, jednakże na tym jedynym z nieformalnych spotkań Gellner głównie milczał (Hall, 2016, s. 15).

Choć ich relacje nie były przyjacielskie, a twórczość Gellnera stała się przedmiotem dość poważnej krytyki ze strony Smitha, zawsze z niezwykłą admiracją wspominał on swego nauczyciela. Okazywał wiele uznania dla jego osiągnięć i inspiracji:

To jego dzieło w 1964 roku po raz pierwszy przyciągnęło moją uwage, kiedy poszukiwałem metod badania zjawisk interesujących mnie od jakiegoś czasu, a które po fali dekolonizacji w Afryce i Azji unosity się w powietrzu. Ernest nie tylko zachęcił mnie do zajęcia się problematyką nacjonalizmu, był promotorem mojego doktoratu; ale dał mi kilka podstawowych lekcji na temat narodu i nacjonalizmu, które później wyznaczały kierunki moich poszukiwań (Smith, 1996b, s. 358).

\section{KARIERA NAUKOWA I PRACA AKADEMICKA}

Swoją pracą doktorską Smith rozpoczął etap w swoim życiu, który można zasadnie nazwać karierą naukową. Jednakże przyszły twórca etnosymbolicznej teorii narodów na początku swojej drogi uczonego wcale nie starał się tworzyć własnego teoretycznego podejścia. Przeciwnie, znajdował się pod przemożnym wpływem Gellnerowskiej modernistycznej teorii narodów.

Chociaż kontakty Smitha z Gellnerem były chłodne w wymiarze relacji osobistych, Gellner doceniał jego zdolności intelektualne i otwartość wobec innych poglądów. Pomimo pewnych różnic w spojrzeniu na narody, na wczesne książki Smitha wpływ miało Gellnerowskie, modernistyczne rozumienie narodów i nacjonalizmu (Malešević, 2016, s. 154).

Jak powiadał Hutchinson, sam Smith w jednej z rozmów zdradził mu, że w trakcie pisania owej monografii wiele z badanych teorii nacjonalizmu musiał sam dopracowywać, albowiem wielu autorów analizowanych przez niego dzieł pisało mgliście, niesystematycznie i bardzo nieściśle. Wówczas przyszło mu do głowy wiele pomysłów, które opracowania doczekały się w późniejszym okresie (Hutchinson, 2016, s. 622).

Pomimo to, jak sam stwierdza: „Byłem wówczas gellneristą, jeżeli to jest odpowiednie słowo. Na pewno byłem modernistą" (Hall, 2016, s. 15). Gellnerowska teoria narodów i nacjonalizmu odcisnęła niezatarty ślad na twórczości Smitha, początkowo stając się przyjętym niemal bezkrytycznie źródłem inspiracji, następnie przekształcając się w przedmiot negatywnego odniesienia (Smith, 1996a, ss. 129-148). Krytyka Gellnerowskiego modernizmu stała się początkiem procesu budowania etnosymbolizmu (Conversi, 2007, s. 19). Twórczość Gellnera, traktowanego początkowo z tak wielką admiracją, stanie się przedmiotem krytyki ze strony Smitha. Reprezentowany przez tego pierwszego moder- 
nizm będzie stanowił swego rodzaju raison d'être etnosymbolizmu, jako przedmiot krytyki właśnie oraz punkt negatywnego odniesienia. Pomimo to sam Gellner, nie zgadzając się z założeniami etnosymbolizmu do swojego byłego podopiecznego zawsze czuł sympatię. Powiadał: "Oczywiście to dla mnie powód do wielkiej dumy, że mój student Anthony Smith stał się czołowym specjalistą w zakresie badań problematyki narodów i nacjonalizmu i wywiera tak ogromny wpływ na tego rodzaju badania" (Gellner, 1996, s. 366).

W pierwszym okresie twórczości naukowej był więc Smith niewątpliwie zwolennikiem modernistycznej teorii narodu i nacjonalizmu. Starał się w Gellnerowskim duchu wskazywać, że narody są produktem nowoczesności, w żadnym wypadku nie istniały w starożytności czy średniowieczu. Towarzyszący narodom nacjonalizm pojawiał się również jako zjawisko charakterystyczne dla nowoczesności jako ideologia legitymizująca nowoczesny porządek społeczny, zastępując tym samym przednowoczesne systemy religijne uprawomocniające porządki polityczne i społeczne w świecie przednowoczesnym. W swoich pierwszych pracach Smith dokonał pewnych korekt Gellnerowskiego modernizmu, umniejszając rolę czynników o charakterze ekonomicznym w procesach nacjogenazy i reprodukcji narodów, przy uwzględnieniu podkreślanej przez Webera roli instytucji nowoczesnego państwa oraz generowanej przez nią nowej intelektualnej i biurokratycznej warstwy społecznej (Hearn, 2018, s. 286). Już wówczas kluczową rolę w procesach tworzenia się i reprodukowania narodu przypisał, jak Durkheim, czynnikom o charakterze religijnym, z czasem pisząc, iż naród to odmiana sacrum, który aby trwać musi cyklicznie odtwarzać własną symbolikę w rytuałach tworzących nacjonalizm, jako swego rodzaju zastępczą formę religii o politycznym charakterze (Grosby, 2018, s. 258). Do prac pisanych zgodnie z duchem modernizmu zaliczyć można wspominane już Theories of Nationalism (1971), The Concept of Social Change (1973), Social Change (1976), Nationalism in the 20th Century (1979). Od modernizmu Smith zaczął odchodzić już w The Ethnic Revival, w którym wprowadzając podstawowe założenia własnej perspektywy teoretycznej, zapowiadał przedstawienie własnej perspektywy teoretycznej (Smith, 1981).

Zasadniczy przełom przyniosła połowa lat osiemdziesiątych XX wieku, wówczas to bowiem opublikował w 1986 roku pionierską książkę The Ethnic Origins of Nations (wyd. pol. 2009) „....tam artykułuje swoje charakterystyczne podejście etnosymboliczne, w którym widział raczej korektę niż alternatywę dla modernizmu" (Hutchinson, 2016, s. 622). Już jednak wówczas wprowadził swoją kategoryzację, dzieląc perspektywy teoretyczne na modernistyczne, perenialistyczne i prymordialistyczne, przeprowadzając coraz to bardziej zdecydowaną krytykę każdej z nich (Antonsich, 2015, ss. 297-310). Obok eksponowanych przez modernistów czynników ekonomicznych, a w większym stopniu politycznych, wskazywał na prymarną w procesach nacjogenezy i formowania się nacjonalizmu rolę kultury i tradycji. Idei głoszącej ściśle nowoczesne pochodzenie narodów zaczął przeciwstawiać pogląd, w którym eksponował ideę długiego trwania wspólnot etnicznych, ich ciągłość. W jego mniemaniu z tych właśnie wspólnot wyłoniły się nowoczesne narody. We wskazanej monografii wyłożył podstawy własnego podejścia, a także wprowadził do obiegu naukowego kategorie pojęciowe, takie jak etnia, etnie demotyczne i lateralne, zespoły mityczno-symboliczne czy ludy wybrane, oraz wiele innych. Wiele z tych pojęć zostało przejętych nawet przez tych badaczy, którzy z głównymi ideami zawartymi w pracach Smitcha się nie zgadzają (Hearn, 2018, s. 292). Na powrót w jego rozważaniach pojawity się zepchnięte przez fascynację Gellnerowskim modernizmem koncepcje brytyjskich historyków, u których pobierał nauki w trakcie studiów, a także koncepcje historyków i socjologów z Durkheimowskiej szkoły Annales, z jakimi zapoznał się w trakcie pobytu 
w Belgii. Nowo utworzoną przez siebie perspektywę teoretyczną Smith nazwat etnosymbolizmem (Özkirimli, 2003, s. 340).

Do zmiany poglądów naukowych skłoniło go kilka rzeczy. Po pierwsze, studiowanie pism Walkera Connora, który zadawał w swoich pismach pytanie: od kiedy istnieje naród? Choć sam Connor stwierdza, że naród istnieje co najwyżej od drugiej połowy XIX wieku, to problematyka genezy narodów wyeksponowana w pismach tego uczonego uczuliła Smitha na procesy nacjogenezy. Kolejnym ze znaczących źródeł inspiracji była twórczość Johna Armstronga, który początki narodów lokował w średniowiecznych i wcześniejszych wspólnotach, wskazując na istotność czynników symboliczno-mitycznych w procesach tworzenia się narodów. Jak sam powiadat, „....jego nacisk na mity, symbole i komunikację był bardzo ważną wskazówką dla drogi, którą obrałem" (Hall, 2016, s. 17). Wiele nauk wyciągnął z dyskusji prowadzonych na seminarium Gellnera, z rozmów z Georgem Schöpflinem ${ }^{6}$ czy Johnem Gillinghamem ${ }^{7}$. Kiedy przed publikacją Etnicznych źródeł narodu przedstawiał swoje pomysły we wcześniejszych publikacjach, na konferencjach i seminariach koledzy i koleżanki narodoznawcy niezgadzający się z jego twierdzeniami ukuli nieco ironiczną nazwę na jego pomysty, twierdzili, że to co przedstawia, to etnosymbolizm. Smith przyjął ją i potraktował ją serio, uważając, że właśnie to określenie dobrze oddaje istotę jego koncepcji (Özkirimli, 2008, ss. 4-6).

Smith zaczął rozwijać swoje podejście etnosymbolicznego tworzenia się narodów w procesach durée longue, gdzie te wyłaniają się z wcześniejszych form w wyniku stopniowej ich transformacji nie zaś rewolucyjnych wydarzeń (Malešević, 2017, s. 148). Nie zgadzał się z modernistami, którzy twierdzili, że narody nie mogły wykształcić się w czasach przed nowoczesnością, albowiem nie było po temu odpowiednich warunków ani instrumentów czy mechanizmów (Conversi, 2007, ss. 15-30). Powiadał, że narody mają głęboko osadzone w przeszłości korzenie etniczne i kulturowe, choć przyznawał rację modernistom, stwierdzając, iż nacjonalizm jako ideologia pojawił się w nowoczesności właśnie. Stwierdzał, że w czasach przednowoczesnych istniały etnie, będące przednowoczesnymi wspólnotami kulturowymi podzielającymi te same mity i społeczną pamięć, zaś narody to nowoczesne ich transformacje. Z etni powstają narody, choć nie ze wszystkich, nie zawsze i nie w każdych warunkach. Tego rodzaju umiarkowany, jeszcze mało radykalny, etnosymbolizm znajduje swój wyraz w książkach Nations and Nationalism in the Global Era (1995), Nationalism and Modernism (1998), The Nation in History (2000). Dziesięć lat po opublikowaniu Etnicznych źródeł narodów na jednej z tzw. Warwick Debates, organizowanych na tamtejszym uniwersytecie, w dniu 25 października 1995 roku doszło do dyskusji pomiędzy Smithem i Gellnerem Obaj wyłożyli swoje podejścia, poddając krytyce koncepcje adwersarza. Ta debata utwierdziła pozycję Smitha jako jednego z wiodących postaci w socjologii narodu (Gellner, 1996; Smith, 1996b).

\section{….}

6 George Schöpflin, właśc. György Schöpflin, (ur. 1939) - węgiersko-brytyjski politolog i polityk. W latach 1950-2004 mieszkał w Wielkiej Brytanii, ukończył tam studia na Uniwersytecie w Glasgow, zaś rok późnie College d'Europe w Brugii. W latach 1963-1967, pracowat w The Royal Institute of International Affairs w Londynie, następnie wykładał w The School of Slavonic and East European Studies na Uniwersytecie Londyńskim, gdzie uzyskał w 1998 r. profesurę. Autor wielu publikacji naukowych, w tym licznych książek, wśród nich: The Hungarians of Rumania (1978), Myths and Nationhood (1997) czy Nations, Identity (2000). Od 2004 r. zasiada w ławach Parlamentu Europejskiego.

7 John Bennett Gillingham (ur. 1940) - historyk urodzony w Londynie i wykształcony na Uniwersytecie w Oksfordzie, emerytowany profesor London School of Economics and Political Science w Londynie. Autor wielu publikacji z zakresu historii średniowiecznej i nowożytnej Anglii, Wielkiej Brytanii oraz historii powszechnej, wśród nich The Kingdom of Germany in the High Middle Ages (900-1200) (1971), The Wars of the Roses: Peace and Conflict in Fifteenth-Century England (1981) czy The English in the Twelfth Century: Imperialism, National Identity, and Political Values (2000). 
W twórczości brytyjskiego klasyka badań narodów i nacjonalizmu wyróżnić można trzeci okres. Smith radykalizuje w nim swoje podejście, stwierdzając, że narody nie tylko wyrastają z przednowoczesnych etni, ale pewne formy narodowe można znaleźć w starożytności i średniowieczu (Jaskułowski, 2009, ss. 312-313). Wskazuje to w szczególności na „...przednowoczesne modele wspólnot politycznych (hierarchicznych, przymierza i republikańskich), które pojedynczo czy w różnych kombinacjach tworzą podstawy dla kształtowania się nowoczesnych narodów" (Hutchinson, 2016, s. 622). To zradykalizowane stanowisko etnosymboliczne wyłożył w licznych tekstach, spośród których najważniejszymi zdają się być The Antiquity of Nations (2004) oraz The Cultural Foundations of Nations (2008); ta ostatnia monografia opublikowana została w języku polskim rok po jej brytyjskim wydaniu.

W trzecim etapie swojej kariery naukowej Smith utwierdził się w przejętym od Durkheima twierdzeniu wskazującym na sakralny charakter narodu i narodowości. W pełni zaadaptował Durkheimowską koncepcję religijnego charakteru funkcjonowania społeczeństw (Hall, 2016, s. 18). Wskazywał na zadziwiająco liczne podobieństwa pomiędzy nacjonalizmem a religią, podkreślał również, że naród traktowany jest przez jego członów jako zjawisko o charakterze sakralnym. Jego członkowie widzą siebie w świętej wspólnocie narodowych pamięci, mitów i rytuałów. Naród traktowany jest jako wybrana wspólnota mająca misję przetrwania i reprodukowania się w przyszłości. Nacjonalizm jest formą religii politycznej, w której naród jest świeckim odpowiednikiem Kościoła, a nawet traktowany jest jako ekwiwalent bóstwa. Sprawia to, że można potraktować podejście etnosymboliczne jako pewną formę neodurkheimizmu (Malešević, 2007, ss. 561-593). Widać to w szczególności w książce Myths and Memories of the Nation (Smith, 1999) oraz w Chosen Peoples (Smith, 2003), a także Ethno-symbolism and Nationalism: A Cultural Approach (Smith, 2009a).

Smith studiował również historię sztuki, z której to dziedziny uzyskał doktorat w 1987 roku. W pracy zatytułowanej Historical Revival in Art in England and France napisanej pod kierunkiem Williama Vaughana ${ }^{8}$ zajął się przemianami w sztuce, głównie w malarstwie i rzeźbie w Wielkiej Brytanii i Francji, a także innych krajach Europy, na przykład w Danii, w okresie pomiędzy 1750 a 1800 rokiem. Pod koniec życia zainteresował się muzyką. Powiadał, że „..historia sztuki jest bardzo pomocną wskazówką w moich głównych badaniach, pozwala mi bowiem widzieć narody i nacjonalizmy w nieco innym świetle" (Hall, 2016, s. 18). Studia nad związkami sztuki z nacjonalizmem oraz kształtowaniem się narodów zostały opublikowane w monografii pod tytułem The Nation Made Real: Art and National Identity in Western Europe, 1600-1850 (Smith, 2013). Tuż przed śmiercią pracował nad publikacją poświęconą związkom muzyki z narodami i nacjonalizmami, nie zdążył jej jednak opublikować, pozostawił tylko jej maszynopis (Hutchinson, 2016, s. 622).

Uczony po ukończeniu prac nad dysertacją na LSE w 1969 roku podjął pracę w charakterze wykładowcy na Uniwersytecie w York. Pracował tam tylko dwa lata, wchodząc w trudne relacje z kilkoma pracownikami naukowymi, którzy, jak podkreślał, w jego mniemaniu byli antysemitami. Na drodze do stabilizacji zawodowej i naukowej na tej właśnie uczelni stanęły także przekształcenia i rywalizacja pomiędzy grupami uczonych mające miejsce na tamtejszym Wydziale Socjologii. Smith przeniósł się na Uniwersytet w Re-

\section{-.....}

8 William Vaughan (ur. 1938) - studiował sztuki piękne w Ruskin School of Arts na Uniwersytecie w Oksfordzie, oraz historię sztuki na Uniwersytecie Londyńskim. Pracowat jako kurator w galerii sztuki Tate Britain. Wykładał historię sztuki na Uniwersytecie Londyńskim, do emerytury w 2003 r. Autor licznych publikacji poświęconych historii sztuki, w tym kilkunastu książek, wśród nich German Romanticism and English Art (1979), British Painting: The Golden Age: From Hogarth to Turner (1999), John Constable (2000). 
ading, gdzie spędził kolejne dziewięć lat. Praca na tej uczelni nie przynosiła mu satysfakcji, publikował mniej, niżby chciał, zaś środowisko naukowe, w jakim przyszło mu pracować, oceniał jako mało stymulujące. Nosił się z zamiarem przejścia na LSE, uczelnię na której studiował socjologię i zdobył stopien doktorski. Nie była to jednakże sprawa prosta, albowiem jego przełożonym na Reading był niechętny jego przenosinom Stanislav Andreski który przyjaźnił się z Gellnerem pracującym w londyńskiej uczelni. Smith zaś nie prosit o protekcję swojego promotora, nie chcąc stawiać go w niezręcznej sytuacji. Niespodziewanie dla samego Smitha jego przenosiny zostały poparte wstawiennictwem i listem polecającym, który napisał nieznany mu wcześniej osobiście filozof Isaiah Berlin.

W 1980 roku Smith podjął upragnioną pracę w LSE. Zaczął piąć się w akademickiej hierarchii, początkowo jako lecturer, nastepnie senior lecturer i reader. W tym czasie wspierał go w staraniach o wyższe stanowiska na uczelni Gellner, który następnie opuścił LSE, by podjąć pracę na Uniwersytecie Cambridge. Po opublikowaniu The Ethnic Origins of Nations starał się o profesurę, ale jej nie uzyskał, głównie w efekcie krytycznej recenzji filozofa Johna Watkinsa ${ }^{10}$, który zarzucił monografii brak ostrości analitycznej. W tym samym czasie profesurę uzyskał Michael Mann, brytyjsko-amerykański socjolog zajmujący się socjologią historyczną, będący przedstawicielem neoweberowskiej odmiany perspektywy modernistycznej w studiach nad narodem i nacjonalizmem i władze wydziału nie widziały możliwości awansowania na stanowisko profesora jeszcze jednego badacza i wykładowcy (Hall, 2016, s. 16). Profesurę otrzymał dwa lata później. W roku 1996 przeniósł się z Department of Sociology do The European Institute, by w 2002 roku rozpocząć pracę w innej jednostce, mianowicie w Government Department, gdzie pracował aż do emerytury w 2004 roku.

Pracując w LSE, Smith opublikował większość swoich tekstów, które przynoszą mu zasłużoną sławę wybitnego znawcy problematyki narodów i nacjonalizmu. Zgromadził wokół siebie grupę uczonych oraz doktorantów, którzy pod jego naukowym kierownictwem uczynią z tego środowiska „...Mekkę nauczania i badań narodów i nacjonalizmu” (Huthinson, 2016, s. 623). Choć budował, co trzeba zauważyć, na bardzo solidnych fundamentach stworzonych przez poprzedników. Założył w 1990 roku wraz ze swoimi uczniami The Association for the Study of Ethnicity and Nationalism (ASEN), wiodące na świecie środowisko badań narodoznawczych i przewodniczył mu do 2013 roku. ASEN organizuje badania, debaty, seminaria i wykłady. Do najważniejszych wydarzeń należą coroczne konferencje naukowe o zasięgu ogólnoświatowym, doroczne Nations and Nationalism Debate i wykłady, które honorując swojego mistrza nazwał The Ernest Gellner Nationalism Lecture. Te ostatnie po śmierci Smitha od 2017 roku zostaną nazwane The Ernest Gellner/ Anthony Smith Nationalism Lecture. Założył również w 1995 roku najczęściej cytowany

9 Stanislav Andreski (właśc. Stanisław Leonard Andrzejewski - 1919-2007) - polsko-brytyjski socjolog. Urodzony w Częstochowie, żołnierz Wojska Polskiego walczący w kampanii wrześniowej 1939 r., wzięty do niewoli przez Armię Czerwoną uciekł z niej, przedostając się do Wielkiej Brytanii. Tam służąc w Polskich Siłach Zbrojnych w Wielkiej Brytanii jeszcze w czasie wojny ukończył eksternistyczne studia na Uniwersytecie Londyńskim, gdzie następnie obronił doktorat. Od 1947 r. pracował na uniwersytetach w Południowe Afryce, Chile i Nigerii. W 1964 r. uzyskał profesurę na Uniwersytecie w Reading, gdzie założył i prowadził Katedrę Socjologii, pracując w niej aż do przejścia na emeryturę w 1984 r. Na emeryturze wykładał socjologię na Polskim Uniwersytecie na Obczyźnie w Londynie. Naukowo zajmował się socjologią polityki, wojska oraz klasyczną teorią socjologiczną. Autor licznych prac, wśród których wymienić można: Military Organization and Society (1954), The African Predicament: A Study in the Pathology of Modernization (1968), Social Sciences as Sorcery (1972) czy Maxa Webera olśnienia i omytki (1992).

10 John William Nevill Watkins (1924-1999) - brytyjski filozof. Profesor w London School of Economics od 1966 r. do przejścia na emeryturę w 1989 r. Zajmował się filozofią nauki, reprezentował nurt noszący nazwę racjonalizmu krytycznego. Napisat m.in.: Hobbes's System of Ideas: A Study in the Political Significance of Philosophical Theories (1965), Science and Scepticism (1984), Human Freedom after Darwin: A Critical Rationalist View (1999). 
w studiach nad narodem i nacjonalizmem periodyk noszący tytuł "Nations and Nationalism", którego do 2013 roku był redaktorem naczelnym.

Wychowat i wykształcit nowe pokolenia wybitnych badaczy problematyki narodów i nacjonalizmów. Wypromował trzydziestu dwóch doktorów, z których do 2016 roku aż dziewięciu uzyskało profesury na prestiżowych uniwersytetach (Huthinson, 2016, s. 623). Wymienić tu można kontynuującego badania realizowane w ramach etnosymbolizmu Johna Hutchinsona, czy tworzącego w paradygmacie modernistycznym Johna Breuilly. Pomimo jego znacznego wpływu na socjologiczne narodoznawstwo oraz tego, że wykształcił znaczącą liczbę uczniów to, jak stwierdza Umut Özkirimli spośród grona znaczących postaci otwarcie za etnosymbolistę uważa się bodajże tylko Huthinson (Özkirimli, 2003, s. 340). Jako promotor, nauczyciel i mistrz Smith był bardzo otwarty na pomysty swoich wychowanków, wspierał ich swoją wiedzą, zachęcał do podejmowania wyzwań naukowych. Z wieloma z nich się przyjaźnił. Aby wspomóc rozwój swoich uczniów, założył w 2001 roku czasopismo "Studies in Ethnicity and Nationalism”, przeznaczone dla młodych naukowców, doktorantów i studentów starszych lat. Publikują tam nie tylko jego wychowankowie, ale także młodzi uczeni z całego świata. Tym samym periodyk staje się swego rodzaju kuźnią młodych narodoznawczych talentów.

\section{PODSUMOWANIE}

Anthony D. Smith na krótko przed przejściem na emeryturę zachorował na białaczkę, „....z którą walczył z wielką odwagą i wytrwałością" (Hutchinson, 2016, s. 624). W ostatnich latach życia coraz więcej czasu spędzał w szpitalu, pisząc jednak w tym czasie kilka książek. Krótko przed śmiercią ukończył monografię poświęconą związkom muzyki i nacjonalizmu, nie zdąży jej jednak opublikować. Umarł 19 lutego 2016 roku. Miarą wartości uczonego jest jego spuścizna naukowa. Smith opublikował 17 książek, które przetłumaczono na 22 języki. Jest autorem ponad 100 artykułów w czasopismach naukowych i rozdziałów w monografiach. Jego prace stanowią pozycje klasyczne w dziedzinie badań narodów i nacjonalizmów. Są erudycyjne, łamią granice naukowych dyscyplin, cechuje je erudycja i ostrość analityczna. Jak wskazuje jeden z jego uczniów, John Hutchinson, poza niepodważalnym wkładem do światowej nauki mierzonym liczbą i jakością publikacji, Smith, ma jeszcze jedną niewątpliwą zasługę. Problematyka narodów i nacjonalizmów stała się

...wydzieloną, interdyscyplinarną dziedziną badań i studiów właśnie dzięki jego zdecydowanym poglądom, które pomogły wskazać główne problemy wymagające przebadania, dzięki tworzeniu wspólnych definicji i klasyfikacji, przez które różne podejścia teoretyczne można porównać, dzięki czemu możliwe staje się utworzenie wspólnego dla dziedziny programu badań (Huthinson, 2016, s. 621).

Nawet krytycy naukowych poglądów Smitha muszą przyznać, że mało kto osiągnął taki status w badaniach narodu i nacjonalizmu (Hearn, 2018, s. 286). Jego nazwisko na stałe weszło do katalogu najważniejszych postaci w badaniach narodoznawczych, jak słusznie podkreślają Eric Kaufmann i Oliver Zimmer, jego wkład w dyscyplinę, podkreślanie historyczności narodów, ich etnicznych oraz sakralnych źródeł na zawsze zmieniło oblicze socjologii narodu (Kaufmann \& Zimmer, 2004, s. 63). Dziś wymienia się go pośród wielkich postaci dyscypliny kładących pierwsze fundamenty pod badania nad narodami Są to nie- 
wątpliwie Karl Deutsch, Hans Kohn czy Carlton Hayes, a także Hugh Seton Watson czy Elie Kedourie. Jego nazwisko wymienia się jednym tchem wraz z nazwiskami Benedicta Andersona i pełniącego w początkowych latach jego działalności naukowej rolę intelektualnego przewodnika Ernesta Gellnera. Na kształt twórczości naukowej poza intensywnym studiowaniem i badaniem interesującej go problematyki wpływ miało jego klasyczne wykształcenie zdobyte w szkołach i uniwersytetach w Wielkiej Brytanii, a także doświadczenia dzieciństwa i historia jego rodziny. Anthony D. Smith stał się nie tylko autorem etnosymbolicznej perspektywy w badaniach nad narodem i nacjonalizmem, to z całą pewnością klasyk historycznej socjologii narodu, a nawet można by pokusić się o stwierdzenie, że to intelektualny fundator interdyscyplinarnego narodoznawstwa.

\section{BIBLIOGRAFIA}

Antonsich, M. (2015). Nations and nationalism. W J. A. Agnew (Red.), The Wiley Blackwell companion to political geography (ss. 297-310). Oxford: Wiley Blackwell. https://doi.org/10.1002/9781118725771.ch22

Connor, W. (2004). The timelessness of nations. Nations and Nationalism, 10(1-2), 3547. https://doi.org/10.1111/j.1354-5078.2004.00153.x

Conversi, D. (2004). Resisting primordialism and other isms. W D. Conversi (Red.), Ethnonationalism in the contemporary world (ss. 270-284). London: Routledge. https://doi. org/10.4324/9780203166246

Conversi, D. (2007). Maping the field: Theories of nationalism and the ethnosymbolic approach. W S. Grosby (Red.), Nationalism and ethnosymbolism: History, culture and ethnicity in the formation of nations (ss. 15-30). Edinburgh: Edinburgh University Press.

Davies, N. (2007). Wyspy: Historia (E. Tabakowska, Tłum.). Kraków: Znak.

Durkheim, E. (2010). Elementarne formy życia religijnego (A. Zadrożyńska, Tłum.). Warszawa: PWN.

Gellner, E. (1996). Ernest Gellner's reply: „Do nations have navels?”. Nations and Nationalism, 2(3), 366-370. https://doi.org/10.1111/j.1469-8219.1996.tb00003.x

Grosby, S. (2018). Nationality and religion. Nations and Nationalism, 24(2), 258-270. https://doi.org/10.1111/nana.12365

Hall, J. (2016). Interview conducted by John A. Hall, Sociology, McGill University, Montreal, Canada on 11 August 2015. Nations and Nationalism, 22(1), 2016, 6-19. https://doi. org/10.1111/nana.12158

Hearn, J. (2018). Power, culture, identity, and the work of Anthony Smith. Nations and Nationalism, 24(2), 286-291. https://doi.org/10.1111/nana.12407

Hutchinson, J. (2016). Professor Anthony D. Smith: An obituary. Nations and Nationalism, 22(4), 621-624. https://doi.org/10.1111/nana.12268

Jaskułowski, K. (2009). Nacjonalizm bez narodów. Wrocław: FNP.

Kaufmann, E., \& Zimmer, O. (2004). „Dominant ethnicity” and the „ethnic-civic” dichotomy in the work of A. D. Smith. Nations and Nationalism, 10(1-2), 63-78. https://doi. org/10.1111/j.1354-5078.2004.00155.x

Kerr, W. (2019). The descent of nations: Social evolutionary theory, modernism and ethno-symbolism. Nations and Nationalism, 25(1), 104-123. https://doi.org/10.1111/ nana. 12426 
Malešević, S. (2007). "Divine ethnies" and "Sacred nations": Anthony D. Smith and the neo-durkhemian theory of nationalism. Nationalism and Ethnic Politics, 10(4), 561-593. https://doi.org/10.1080/13537110490900331

Malešević, S. (2016). In memoriam: Anthony D. Smith (1939-2016). Politicka Misao, 53(2), 153-156.

Malešević, S. (2017). The foundations of statehood: Empires and nation-states in the longue durée. Thesis Eleven, 139(1), 145-161. https://doi.org/10.1177/0725513617701925

Özkirimli, U. (2003). The nation as an artichoke? A critique of ethnosymbolist interpretations of nationalism. Nations and Nationalism, 9(3), 339-355. https://doi. org/10.1111/1469-8219.00100

Özkirimli, U. (2008). The double life of John Hutchinson or bringing ethno-symbolism and postmodernism together. Nations and Nationalism, 14(1), 4-9.

Smith, A. D. (1971). Theories of nationalism. New York, NY: Torchbook Library Edition.

Smith, A. D. (1973). The concept of social change. London: Routledge \& Kegan Paul.

Smith, A. D. (1976). Social change. London: Longman.

Smith, A. D. (1979). Nationalism in the twentieth century. Canberra: Australian University Press.

Smith, A. D. (1981). The ethnic revival. Cambridge: Cambridge University Press.

Smith, A. D. (1995). Nation and nationalism in a global era. Cambridge: Polity.

Smith, A. D. (1996a). History and modernity: Reflection on the theory of nationalism. W A. Grosby \& A. S. Leoussi (Red.), Nationalism and ethnosymbolism (ss. 129-148). Edinbourgh: University Press.

Smith, A. D. (1996b). Nations and their pasts. Nations and Nationalism, 2(3), 358-365. https://doi.org/10.1111/j.1469-8219.1996.tb00002.x

Smith, A. D. (1998). Nationalism and modernism. London: Routledge.

Smith, A. D. (1999). Myths and memories of the nation. Oxford: Oxford University Press.

Smith, A. D. (2000). The nation in history: Historiographical debates about ethnicity and nationalism. Cambridge: Polity Press.

Smith, A. D. (2003). Chosen peoples. Oxford: Oxford University Press.

Smith, A. D. (2004). The antiquity of nations. Cambridge: Polity Press.

Smith, A. D. (2009a). Ethno-symbolism and nationalism: A cultural approach. London: Routledge. https://doi.org/10.4324/9780203876558

Smith, A. D. (2009b). Etniczne źródła narodów (M. Głowacka-Grajper, Tłum.). Kraków: Znak.

Smith, A. D. (2009c). Kulturowe podstawy narodów (W. Usakiewicz, Tłum.). Kraków: UJ.

Smith, A. D. (2013). The nation made real: Art and national identity in Western Europe, 1600-1850. Oxford: Oxford University Press.

Zins, H. (2001). Historia Anglii. Wrocław: Zakład Narodowy im. Ossolińskich. 